\title{
PiJaństwo górników Na Górnym ŚląsKu w DRUGIEJ POŁOWIE XIX WIEKU I W PIERWSZEJ POŁOWIE WIEKU XX - PORTRET ZBIOROWY
}

\author{
Katarzyna Kubica \\ kasiaa178@02.pl
}

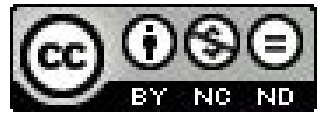

\section{WPROWADZENIE}

Praca ta, chociaż dotyczy wydarzeń mających miejsce w XIX i XX wieku, swym zasięgiem obejmuje granice dzisiejszego Górnego Śląska, jednak bez Zagłębia Dąbrowskiego.

Pijaństwo - czy to już to samo, co alkoholizm? Najtrafniej różnicę między tymi dwoma zagadnieniami określa stare francuskie porzekadło: „pijak mógłby przestać pić, gdyby chciał - alkoholik chciałby przestać pić, gdyby mógł"1. Są to kwestie odmienne, jednak nie do końca, ponieważ tym, co je łączy, jest alkohol. Zatem cel jest wspólny - spożywanie alkoholu. Różnica więc musi polegać na powodach, jakimi kierują się alkoholik i pijak sięgając po alkohol. Alkoholik jest uzależniony od alkoholu, pije, bo nie potrafi zapanować nad swoją choroba, nie potrafi oprzeć się psychicznym doznaniom, jakie zapewnia ten środek odurzający. Z kolei pijak potrafi kontrolować ilość spożywanego przez siebie alkoholu, jednak pije, ponieważ obyczaj panujący $\mathrm{w}$ domu czy środowisku, w jakim żyje, niejednokrotnie uniemożliwia mu podjęcie innej decyzji. Zatem pijaństwo i alkoholizm nie oznaczają w mojej pracy tego samego zjawiska, a rozróżnienie między tymi dwoma określeniami zostało wprowadzone celowo. Z drugiej strony, opisując pijaństwo górników, nie sposób pominąc istoty alkoholizmu, gdyż zjawisko to występowało na dużą skalę w drugiej połowie XIX i pierwszej połowie XX wieku na Górnym Śląsku.

Druga połowa XIX wieku to okres wielkich zmian w przemyśle górniczym, charakteryzujący się przyspieszonym tempem rozwoju, przemianami technicznymi, a także przyrostem produkcji i zatrudnienia². Dla omawianego zagadnienia ważna jest zwłaszcza ta ostatnia kwestia. Przejście od okresu przedindustrialnego do industrialnego cechowało się zwiększeniem obszaru koncentracji przemysłu a co za tym idzie, pozwoliło na zatrudnienie większej ilości górników w kopalniach. Wraz z powiększaniem się ich liczby możemy mówić o narodzinach kultury górniczej, która rozwijała się od drugiej połowy XIX w. Jej stopniowy rozkład rozpoczął się w dwudziestoleciu międzywojennym, zaś jej zanik nastąpił po drugiej wojnie światowej. Właśnie w tym okresie tradycyjne wzory zachowań środowisk górniczych były mocno związane z pijaństwem, dlatego ramy czasowe, które przyjęłam, aby omówić ten problem, odpowiadają czasowi trwania kultury górniczej.

W pracy pojawiają się charakterystyczne dla gwary śląskiej zwroty. Zostały one użyte w przytoczonych relacjach górników. Celowo nie poprawiałam tych wypowiedzi, żeby nie zmieniać ich sensu. Wielokrotnie sięgałam po bezpośrednie relacje członków rodzin górniczych, gdyż, moim zdaniem, najlepiej oddają atmosferę tamtych lat.

\section{PrZYCZYNY SIĘGANIA PO ALKOHOL}

Alkohol na Górnym Śląsku w minionych stuleciach towarzyszył człowiekowi niemalże na każdym etapie jego życia. Przewijał się przez każde święta i uroczystości, zarówno świeckie, jaki i religijne. Najwięcej jednak okazji do świętowania mieli w tamtym okresie górnicy. Związane to

1 A. Olejnik, Pijaństwo a alkoholizm, http://www.adamolejnik.com/blog/2008/02/13/pijanstwo-a-alkoholizm/,30.05.2010.

2 S. Michalkiewicz, Przemyst i robotnicy na Ślasku, Katowice 1984, s. 17.

3 Więcej na ten temat patrz: M. G. Gerlich, Rytm i obyczaj. Cztery szkice o tradycyjnej kulturze górniczej, Zabrze 2003. 
było w głównej mierze z wykonywanym przez nich zawodem. Każdy etap związany z osiagnięciami zawodowymi musiał być suto zakrapiany alkoholem.

Nowicjusz, rozpoczynający etat w kopalni, wkupywał się do pewnego kręgu osób, z którymi miał od tego momentu pracować. Wkupywanie się polegało przede wszystkim na uraczeniu współtowarzyszy pracy obfitym poczęstunkiem i dużą ilością alkoholu. Młodzi górnicy często podkreślali, że podczas takich biesiad starsi koledzy dążyli do ich upojenia: „wiela razy słyszałem, że jak się stawia pierwszą wódkę, to człowieka chcą uchlać. Potem mogom się z tego śmiać. Jak ja dałem kolegom pierwszą wódkę, to pamiętam, że w głowie też mi dobrze szumiało. Dymiło mi, ile wlezie, a ciagle słyszałem, że trzeba pić, bo co to za górnik, co nie umie wypić (... ."'4. Ostatnie zdanie w wyżej wymienionej relacji pokazuje, że starsi górnicy w sposób bezpośredni wywierali psychiczną presję na swoim młodszym koledze. Niedoświadczony jeszcze, młody człowiek, zupełnie nieświadomy zagrożenia, przeważnie ulegał namowom. Czynił to nie tylko dlatego, że nie wytrzymywał presji i czuł nad sobą przewagę swych zorientowanych w sytuacji kompanów, ale przede wszystkim dlatego, by zostać przez nich zaakceptowanym i dopuszczonym do łask. Było to bardzo ważne. Gdy młody górnik wkupił się do górniczego kolektywu, nie musiał się już obawiać ich gniewu, wyższości czy wyszydzenia. Uległ namowom kompanów, dlatego mógł się czuć prawdziwym górnikiem, realnie przyjętym do zawodu. Odmowa groziła odrzuceniem, poczuciem izolacji od reszty górników, co dla nowoprzyjętego było równe z przegrana, bo w ciężkich kopalnianych warunkach musiałby polegać tylko na sobie. Gdy postawił odpowiednią ilość alkoholu i do tego pokazał, że potrafi dużo wypić, mógł liczyć na pomoc starszych pracowników w każdym momencie.

Niemal identyczna sytuacja miała miejsce podczas pierwszej wypłaty młodego górnika. Nowicjusz musiał przejść przez pewien rytuał, który gwarantował mu akceptację nowej grupy ${ }^{5}$. Każdy awans, sukces czy ważna chwila w życiu górnika musiała być suto zakrapiana alkoholem. Nie chodziło tylko o picie dla samej przyjemności. Każdemu podniosłemu wydarzeniu towarzyszyła wódka, ponieważ traktowano ją jako nieodłączny element obrzędów. W tradycji górniczej było zaś bardzo dużo różnych zwyczajów związanych z wykonywanym zawodem, co odróżniało ludzi pracujących pod ziemią od reszty społeczeństwa górnośląskiego. Upijanie się było zatem często efektem ceremoniału, częścią pewnych norm zachowania, do których górnik musiał się dostosować, jeżeli chciał zaistnieć w oczach kompanów.

Robotnik w XIX wieku to homo faber, który pół dnia spędzał w pracy ${ }^{6}$. Górnicy pracowali w ciężkich, zagrażających ich zdrowiu i życiu, warunkach. Byli traktowani prawie jak niewolnicy, a ich pensje były tak małe, że nieraz nie wystarczały na utrzymanie rodziny. Bardzo często byli poniżani, karani i bici przez swych przełożonych7. Praca w tak ciężkich warunkach powodowała napięcie, z którym robotnik pracujący pod ziemią często sobie nie radził. Pozbawiony nadziei i nie widząc perspektyw na lepszą przyszłość, wielokrotnie sięgał po alkohol, który na jakiś czas pozwalał mu nie myśleć o jego tragicznym położeniu. Górnik szukał pocieszenia w wódce, pijąc z kolegami w karczmie. Pił najczęściej ze współtowarzyszami pracy. W takim towarzystwie był doskonale rozumiany, ponieważjego koledzy przeżywali codziennie to samo, co

\footnotetext{
4 Relacja anonimowego informatora zamieszczona [w:] M. G. Gerlich, Rytm..., s. 50.

5 Tenże, Rytm..., dz. cyt., s. 49. Sytuację tę dobrze opisuje jeden z górników por. tenże, Zawód górnika a tradycyjne wzory zachowań, [w:] D. Simonides (red.), Górniczy stan w wierzeniach, obrzędach, humorze i pieśniach, Katowice 1998, s. 70.

6 J. Wycisło, Model robotnika chrześcijańskiego w ujęciu górnoślaskiego czasopisma "Praca” (1890-1891), „Śląskie Studia Historyczno-Teologiczne" 1982, R. XV, s. 139

7 Więcej o warunkach pracy patrz: J. Jaros, Historia górnictwa wẹglowego w Zagłębiu Górnoślaskim do 1914 roku, Wrocław-Warszawa-Kraków 1965, s. 220-255.
} 
on. Mogli zatem wspólnie narzekać na swą ciężką dolę i przy odpowiednim trunku wzajemnie dodawać sobie otuchy. Alkohol dawał zatem chwilowe ukojenie. Za te chwile szczęścia robotnik płacił jednak wysoką cenę - zostawiał w karczmie wielką część swojej i tak już niskiej pensji.

Prasa w XIX wieku kładzie nacisk na budzący dość duże wątpliwości, z dzisiejszego punktu widzenia, powód pijaństwa górników. Związany był on z kobietami. Czasopismo „Katolik” protestuje przeciw pracy kobiet $\mathrm{w}$ fabrykach, kopalniach i hutach, ponieważ swą pracą przyczyniają się do pijaństwa mężów, a tym samym to one odpowiadają za niszczenie rodzin. Gazeta twierdzi, że pracując w młodości, kobieta po wyjściu za mąż nie jest przygotowana do pełnienia roli matki i żony, dlatego mąż musi wyręczaćją we wszystkich jej obowiązkach. Po jakimś czasie nie może już tego znieść, więc zamiast wracać po pracy do domu, woli się udać ",do knajpy, aby się zagrzać jednym, przychodzi podchmielony do domu, klnie, wyzywa, bije". ${ }^{9} \mathrm{~W}$ mentalności ludzi XIX wieku, nie tylko górników, miejsce kobiety było w domu. Jednak taki sposób myślenia u większości Górnoślązaków można było spotkać jeszcze w drugiej połowie XX wieku ${ }^{10}$. Kobiety nie pracowały zawodowo nie tylko dlatego, że musiały zajmować się domem i dziećmi. Dla każdego mężczyzny tego okresu punktem honoru było, aby zarobić na utrzymanie rodziny samodzielnie. Gdy zaś, z powodu zbyt małych zarobków męża, kobieta musiała iść do pracy, mężczyzna czuł, że nie wypełnia prawidłowo swej roli ${ }^{11}$. Zatem przykład opisany wyżej, w jednym z artykułów „Katolika”, może nie do końca odzwierciedlać prawdę, a być tylko wskazówką dla kobiet, aby darzyły swych mężów uznaniem i nie wypełniały obowiązków, które od dawna przypisane są mężczyznom. Nie jest to oczywiście jedyna możliwa interpretacja teksu gazety. Jak już zostało wspomniane, miejsce kobiety było w domu. To ona miała dbać o dzieci, porządek, przygotowywać posiłki. Jeżeli zaś w młodości pracowała w hucie, kopalni czy fabryce po 12 godzin dziennie, nie była w stanie dobrze przygotować się do wykonywania tych powinności. W poprzednich stuleciach każdy pełnił określoną rolę, przypisaną mu ze względu na płeć. Gdy ktoś sprzeciwiał się z góry określonemu porządkowi, był najczęściej źle odbierany przez resztę społeczeństwa ${ }^{12}$. I w tym wypadku mogło być podobnie. Mąż mógł sobie nie radzić z nowym, niespotykanym wcześniej rozkładem zadań, nie akceptować zastanych zmian, a nawet odczuwać wstyd, będąc wyśmianym przez kolegów. Nie widząc innego wyjścia, być może wybierał alkohol, który na jakiś czas pozwalał mu zapomnieć o rzeczywistości. Nie można więc patrzeć na ten przykład tylko z jednego punktu widzenia. Podane wydarzenia miały miejsce około 120 lat wcześniej, a realia życiowe były wtedy zupełnie inne i należy wziąć je pod uwagę.

Dotychczas opisane zostały tylko przyczyny pośrednie, które wpływały na decyzję o sięganiu po alkohol. Jednak wielokrotnie górnicy sami, nie prowokowani przez innych, wysuwali argumenty, które miały tłumaczyć ich pijaństwo. Pod ziemią panowały specyficzne, trudne warunki, które zmieniały pracujących tam ludzi. Jak pisze Gustaw Morcinek, górnik, kiedy pracuje pod ziemia, przemienia się w innego człowieka, w mistyczną postać, która musi stawić czoła śmierci ${ }^{13}$. Z opisu tego wynika pewna różnica, którą górnicy odczuwali względem pozostałych grup zawodowych. Odmienność ta wynikała z poczucia dumy zawodowej, zaangażowania wkładanego w wykonywaną przez siebie pracę i korzyści, jakie niosła dla całego społeczeń-

\footnotetext{
8 Mężowie - górnicy prawie w ogóle nie rozmawiali z żonami o swej pracy.

9 Sprawy społeczne, „Katolik” 1887, nr 42. Cyt za: W. Janota, Górny Sląsk przed stu laty. Jak o nim gazety owoczesne pisaty, Katowice 1984, s. 39-40.

10 Wnioski z badań własnych.

11 W. Mrozek, Górnoślaska rodzina robotnicza w procesie przeobrażeń, Katowice 1987, s. 138-153.

12 E. Górnikowska-Zwolak, Szkic do portretu Śląaczki. Refleksja feministyczna, Katowice 2004, s. 79-94.

13 M. Żywirska, Życiorysy górników, Katowice 1949, s. 9.
} 
stwa ${ }^{14}$. Poczucie wyższości towarzyszyło pracownikom dołowym nie tylko w pracy, ale także w domu czy wśród znajomych innej profesji. Mając takie wyobrażenie o sobie, górnicy czuli, że wstępowanie do karczmy, po wielogodzinnym wysiłku, niejako należy im się z urzędu ${ }^{15}$. Jednak często nie potrafili poprzestać na ,,jednym piwie", a wtedy krótkie wizyty w lokalach zamieniały się $\mathrm{w}$ wielogodzinne biesiady, w których nie widzieli nic złego, bo przecież im się należało... W ten sposób niewinny, usprawiedliwiony relaks po pracy przemieniał się, wcale nierzadko, w plagę pijaństwa, która w jednoznaczny sposób zmieniała życie rodziny w gehennę.

Na szybkie rozprzestrzenianie się pijaństwa wpływ miała także duża ilość karczm, dzięki czemu alkohol był łatwo dostępny ${ }^{16}$. Do kupna dużej ilości trunków zachęcała górników niska cena tego produktu. Niejednokrotnie zdarzało się, że robotnicy brali kredyt, który był udzielany przez handlarzy żydowskich. Tak zaciagniętą sumę często przepijali, a nie mogąc spłacić długów, popadali w nędzę $e^{17}$. Tym samym doprowadzali do bankructwa całą swoją rodzinę. Żydom przypinano łatkę karczmarza, rozpijającego Ślązaków. W ten sposób powielano istniejący od dawna stereotyp Żyda - nieuczciwego człowieka, który dąży jedynie do powielenia zysku, nawet kosztem ludzkiego nieszczęścia. Ta krążąca w społeczeństwie krzywdząca opinia była często przytaczana w prasie ${ }^{18}$. Traktowano zatem Żydów jako współodpowiedzialnych za istnienie pijaństwa, a co za tym idzie - przyczyniających się do ubożenia rodzin.

\section{OD KOłYSKI AŻ PO GRÓB}

Pijaństwo górników nie było oczywiście związane tylko z pracą w kopalni. Okazji do przyjęć dostarczały też uroczystości rodzinne, a więc zaręczyny, śluby, urodziny, chrzty czy pogrzeby.

Gdy dochodziło do zaręczyn, alkohol pełnił przede wszystkim funkcję symboliczna, ponieważ wypicie go przez gospodarzy było wynikiem zgody i akceptacji na zawarcie małżeństwa ${ }^{19}$. Pewien górnik tak opisał to wydarzenie: ,jak już się siedziało przy stole, (...) to się gorzołka potym piło. Gorzołka zawsze musioł przynieść synek. Stawioł ją po tym, jak już wiedzioł, ze wszystko idzie po jego myśli. Wypiło się tako gorzałka, to kożdy wiedzioł, że swoja pieczątka doł. Jo pamiętom, że przyszedł żech nazod do dom, to ojciec mie spytoł, jak było. Powiedziołech mu, że zgoda mi dali, zjedli my i wypili. To on mi godo: Jak żeście wypili, to kożdy swoją zgode podpisoł już"20. Warto dodać, że choć ingerencja rodziców w wybór partnera była na Górnym Śląsku minimalna, to jednak często doradzali swym pociechom. Podpowiadali jaki powinien być ich przyszły zięć, na pierwszym miejscu podkreślając, że nie może on być alkoholikiem.

Podczas pożegnania stanu kawalerskiego przyszły małżonek organizował przyjęcie dla kolegów. Nie ma jednoznacznych podań, które potwierdzałyby obecność alkoholu w czasie takich zabaw. Przyjęcia te różniły się od reszty uczt. Ich celem nie było upojenie. Przyszły małżonek zapraszał parę osób, zazwyczaj byli to koledzy z pracy. Było to miłe spotkanie, podczas którego wspominano stare czasy, śpiewano i grano na instrumentach ${ }^{21}$. Uważam, że alkohol był w czasie takiej zabawy sprawą indywidualną każdego przyszłego małżonka, być może to on decydo-

14 I. Bukowska-Floreńska, Rodzina na Górnym Śląsku, Katowice 2007, s. 130-131.

15 Wnioski z badań własnych.

16 I. Bukowska-Floreńska, Rodzina..., dz. cyt., s. 225

J. Ziemba, Stroma na dót drabina, Katowice 1983, s. 123.

Lipiny, „Katolik” 1879, nr 51. Cyt za: W. Janota, Górny Ślaask przed stu laty..., dz. cyt., s. 43-44.

9 H. Gerlich, Narodziny, zaślubiny, śmierć, Katowice 1984, s. 56-58.

20 H. Gerlich, M. G. Gerlich, Zwyczaje, obyczaje i obrzędy rodzinne w miastach Górnego Śląska, „Zaranie Śląskie” 1989, R. LII, nr 3-4, s. 395.

${ }^{21}$ H. Gerlich, Narodziny..., dz. cyt., s. 64-65. 
wał czy i w jakiej ilości się pojawi. Jednak całkowity jego brak uważany był za brak gościnności, więc można przypuszczać, że kawaler stawiał wódkę kolegom. Przyjemna zabawa nie zmieniała się jednak w huczną biesiadę.

Przed uroczystością weselną przyszli małżonkowie zobowiązani byli do jeżdżenia z kołaczem ${ }^{22}$. Zaproszonym gościom, ale nie tylko, młodzi rozdawali kołacz, za który najczęściej otrzymywali na miejscu symboliczny kieliszek wódki, a zdarzało się, że z tego powodu zapraszano ich do domu i wznoszono toasty za narzeczonych.

Wesele było szczególną uroczystością na Górnym Śląsku. Był to czas ogromnej radości, ponieważ powiedzenie sobie sakramentalnego "tak" wiązało się z huczną zabawa, wystawnością i obfitością. Rodzice młodej pary musieli wręcz zadbać o to, aby jedzenia i alkoholu było w nadmiarze ${ }^{23}$. Gdyby czegoś zabrakło, okryliby się hańbą i byliby „na językach” całej okolicy. Gdy rodzice pary młodej byli biedni, uzyskiwali pomoc w organizacji wesela od bliskich i znajomych, aby biesiada była wystawna. Można zatem powiedzieć, że przyjęcie było urządzane na pokaz, aby zadowolić gości i zadbać o dobry wizerunek rodziny. W takim znaczeniu wesele może być traktowane jako synonim słowa pijaństwo. Biesiadnicy swoim zachowaniem wręcz domagali się od gospodarzy podania wódki, bo bez niej uroczystość byłaby smutna, wręcz jak na stypie ${ }^{24}$. Toteż przebieg wesela wynikał z ilości spożytego przez gości alkoholu - były śpiewy, tańce i głośna muzyka. Wódka, piwo i wino odgrywały główną rolę w całej zabawie, gdyż na ich cześć śpiewano nawet hymny. Obecność alkoholu traktowano nie tylko jako dobry zwyczaj rodziny pary młodej - był to raczej nakaz, gdyż od niego zależało zadowolenie przybyłych gości, dobra opinia i szacunek społeczny. Hulano nie tylko w dniu ślubu. Dni przeznaczone na poprawiny zależały od decyzji rodziców młodych małżonków. Zazwyczaj był to jeden dzień, ale zdarzało się, że pijaństwo trwało przez trzy kolejne dni.

Narodziny każdego nowego potomka w rodzinie górnośląskiej było ważnym wydarzeniem. Wiązało się z nim kultywowanie pewnych zwyczajów. Gdy nowy potomek przyszedł na świat, obowiązkiem ojca było częstowanie sąsiadów i bliskich alkoholem, gdyż należało wypić za zdrowie noworodka. Szczególnie świętowano przy narodzinach pierwszego dziecka, zwłaszcza syna: , ,jak się górnikowi urodzi pierwszy syn czy nawet córka, to chodzi teraz pijany od urodzenia aż do chrzcin. a potem jeszcze z tydzień po chrzcinach, bo musi najpierw opić, że się dziecko urodziło, a potem, że go ochrzcili"25. Podczas gdy matka noworodka odpoczywała i regenerowała siły, ojciec świętował i ogłaszał z kieliszkiem narodziny dziecka. Z dzisiejszego punktu widzenia takie zachowanie męża wydaje się karygodne, zwłaszcza okiem kobiety. Jednak wśród dawnych mieszkańców Górnego Śląska był to powszechny zwyczaj, który w dużej mierze miał wpływać na pomyślność rozwoju dziecka. Górnoślązacy wierzyli w różne przesądy, a ich nieprzestrzeganie miało przynieść złe skutki. Picie za zdrowie dziecka było zatem jedną z metod prewencyjnych, chroniło dziecko od nieszczęść, miało zapewnić pomyślność.

Każda śląska rodzina starała się po uroczystości kościelnej chrzcin zorganizować przyjęcie. Najbiedniejsze rodziny urządzały biesiadę przynajmniej pierworodnemu potomkowi. Wystawna musiała być zwłaszcza uroczystość organizowana przez rodziny górnicze. Chrzciny musiały

22 I. Bukowska-Floreńska, Rodzina... , dz. cyt., s. 195.

23 Takich chwil nie było w życiu dawnych Górnoślązaków za wiele. Z powodu biedy, rzadko spożywali mięso, dlatego okres wielkich uroczystości traktowali jako możliwość najedzenia się do syta.

24 Wnioski z badań własnych.

25 Relacja anonimowej informatorki zamieszczona [w:] H. Gerlich, Narodziny..., dz. cyt., s. 48. 
być suto zakrapiane alkoholem, wszyscy musieli wypić za zdrowie dziecka ${ }^{26}$. W świadomości ludzi krążyło nawet powiedzenie: „u górnika chrzciny to jak na wsi wesele”27. Toteż na górnikach ciążyła powinność zorganizowania hucznej biesiady, co było dosyć uciążliwe dla ubogich i wielodzietnych rodzin. Brano jednak pod uwagę położenie materialne rodziców nowonarodzonego dziecka, dlatego też w tym wypadku nie miał miejsca przymus, który panował w czasie organizowania uroczystości weselnej.

W pierwsze urodziny organizowano tzw. „roczek”, który był popularny zwłaszcza wśród rodzin górniczych. Po niedzielnej mszy rodzice zapraszali bliskich na przyjęcie. Jego wystawność zależała od zamożności rodzin, które starały się, aby urządzić je możliwie okazale. Uroczystość ta była skromniejsza od uroczystości chrzcin. Świętowano jednak, ponieważ: „roczek to już wszystko dobrze. (...) Jak roczek, to kobiety wiedziały, że idzie chodzić z drugim" ${ }^{28}$. Zatem "roczek" stanowił pewien etap w życiu małego człowieka. Przetrwał on okres, w którym był najbardziej narażony na choroby i śmierć. Rodzice wznosili toasty za dalsze zdrowie swej pociechy i dziękowali za przeżyty rok. Kończyła się w pewnym sensie niepewność o życie malca, gdyż kolejne niebezpieczeństwo czekało na niego dopiero w kopalni.

Także śmierć była okazją do spotkań w gronie najbliższych. Po pogrzebie najbliższa rodzina zmarłej osoby organizowała stypę, na którą zapraszano najbliższych krewnych i znajomych. Uczta pogrzebowa także była organizowana według funkcjonującego wśród lokalnej społeczności wzorca. Stypa górnika powinna być wystawna. Miejscowa ludność wywierała presję na rodzinę zmarłego górnika, aby uczta organizowana po jego śmierci była suto zakrapiana alkoholem. Wszelkie odstępstwa od przyjętych norm wywoływały niezadowolenie świadków wydarzeń29. Zwracano wielką uwagę na wystawność uczty pogrzebowej, na ilość alkoholu i pożywienia, a także publicznie wyrażano swoje niezadowolenie w przypadku, gdy stypa była skromna. Obecność alkoholu była konieczna ze względu na zwyczaj „polewania skórki”. Był to toast za zmarłego ${ }^{30}$. W ten sposób oddawano cześć i szacunek zmarłemu. W miarę ilości spożytego alkoholu, stypa zmieniała swój charakter - ze smutnej uroczystości przeobrażała się nieraz w wesołe przyjęcie ${ }^{31}$.

Ważna dla rodzin górniczych była też rocznica śmierci. Rodzina zmarłego zamawiała mszę, po której zapraszała na małe przyjęcie najbliższych. Jak na każdym przyjęciu, starano się zapewnić odpowiednią ilość alkoholu i pożywienia dla gości.

Na osobne omówienie zasługuje największe górnicze święto zwane Barbórką. Dzień 4. grudnia obchodzony jest $\mathrm{w}$ roku kościelnym jako dzień św. Barbary ${ }^{32}$, patronki górników. Z tego też powodu górnicy zbierali się co roku w kościele na mszy świętej, aby oddać cześć swej patronce, podziękować za opiekę i prosić o dalsze łaski. Po części oficjalnej mijała powaga i przystępowano do hucznej zabawy w karczmie, a czasami na terenie kopalni. W tym dniu naczelnik kopalni często rozdawał górnikom wódkę. Biesiada górnicza była wielkim wydarzeniem, niejednokrotnie górnicy świętowali wtedy z całymi rodzinami. Można powiedzieć, że alkohol był „głównym daniem" uczty barbórkowej, a sposób zachowania biesiadników wynikał z ilości spożytego 
trunku ${ }^{33}$. Głośna zabawa była częścią Barbórki. Skoro całe życie górnika było związane z alkoholem, trudno sobie wyobrazić, aby w dniu swojego święta mógł dobrowolnie zrezygnować z wódki i piwa. Można nawet powiedzieć, że skoro był to jego dzień, to pozwalał sobie na więcej niż zazwyczaj, dlatego też biesiada górnicza kończyła się zazwyczaj tak, jak to zostało wyżej opisane. Picie w Barbórkę było niemalże obowiązkiem każdego górnika, gdyż jak głosi przysłowie: „kto w Barbórka nie pije, tego w grubie zabije" ${ }^{\prime 34}$. W Barbórkę wznoszono także toasty za nowych górników i przyjmowano ich do górniczego grona. Stawianie wódki w Barbórkę to kolejny element obrzędu, który był związany z wkupywaniem się w łaski ${ }^{35}$.

\section{ISTOTA PROBLEMU PIJAŃSTWA W OCZACH WSPÓŁCZESNYCH}

Pijaństwo było plagą tamtego okresu, dlatego też było powszechnie zauważalne. Na istotę tego problemu uwagę zwracali zarówno propagatorzy wstrzemięźliwości, redaktorzy gazet, kierownicy kopalń, jak też sami górnicy i ich żony.

Pijaństwo górników musiało utrudniać życie zwłaszcza ich żonom. To one zajmowały się domem i dziećmi, dbały o gospodarstwo i organizację życia codziennego ${ }^{36}$. Ich życie było monotonne, codziennie wykonywały szereg obowiązków, dlatego też skarżyły się na swoje położenie. Ubolewały zwłaszcza nad swoimi partnerami, którzy przepijali część wypłaty i często chodzili do karczmy. Toteż z omawianego okresu pozostały charakterystyczne relacje kobiet, które żaliły się na swój $\operatorname{los}^{37}$. Kobiety nie miały lekkiego życia, pijaństwo mężów było dla nich wielkim utrapieniem. Jedne próbowały z tym walczyć, inne zaś pokornie przyglądały się sytuacji i cierpiały w milczeniu. Żale kobiet stawały się czasami tłem opowieści górniczych czy ludowych pieśni. Autorkami opowieści realistycznych , których tematem jest picie wódki, są głównie kobiety w ten sposób piętnowały nałóg swych mężów ${ }^{38}$.

Ciekawym kobiecym sposobem na walkę z nałogiem było topienie marzanioka. Kobiety, które borykały się z pijaństwem swych mężów, wierzyły, że marzanna wynosi z domu nie tylko choroby, ale i zamiłowanie do wódki. Toteż zmieniały nieco kukłę i charakteryzowały ją na podobieństwo mężczyzny. Tak powstałemu marzaniokowi, wkładały do ręki butelkę z woda, a do kieszeni szklankę. Gotową już kukłę dziewczyny wrzucały do rzeki, zaś kobiety, które odczuwały skutki nałogu swych mężów, stały na moście lub brzegu rzeki i obserwowały tonięcie marzanioka ${ }^{39}$. Jednak, jak podkreślały z uśmiechem na ustach kobiety, najprostszym sposobem na oduczenie męża przepijania wypłaty, był wałek do ciasta ${ }^{40}$, który stał się z czasem tematem ślaskich żartów.

Zdarzało się, i to wcale nierzadko, że mężowie pod wpływem alkoholu nie panowali nad swymi emocjami i znęcali się fizycznie nad żonami: „,niyftore kobiyty miały się bardzo ciynżko. Chłop, jak i se casym wypioł, móg(ł) i piznońć abo inno krzywda zrobić. Chłopy casym biyli baby (...). Strasyli, że je wyciepnom (...) $)^{\prime \prime 41}$. Niektóre kobiety podkreślały nawet, że fizyczne znęcanie się pijanych mężów nad żonami było popularne w każdej rodzinie ${ }^{42}$.

\footnotetext{
33 Od Katowic, „Katolik” 1885, nr 1. Cyt za: W. Janota, Górny Ślask przed stu laty..., dz. cyt., s. 117.

34 D. Czybala, Przystowia górnicze, [w:] D. Simonides (red.), Górniczy stan w wierzeniach..., dz. cyt., s. 418.

M. G. Gerlich, Rytm..., dz. cyt., s. 64.

I. Bukowska-Floreńska, Rodzina..., dz. cyt., s. 131-132.

M. G. Gerlich, Rytm..., dz. cyt., s. 94-95.

J. Hajduk-Nijakowska, Opowieści górnicze, [w:] D. Simonides (red.), Górniczy stan ..., dz. cyt., s. 147-148.

D. Simonides, Najpiękniejsze zwyczaje i obrzędy górnoślaskie, Katowice 1995, s. 31.

Wnioski z badań własnych

Relacja Gertrudy K. zamieszczona [w:] E. Górnikowska-Zwolak, Szkic do portretu..., dz. cyt., s. 131.

Relacja mieszkanki Radzionkowa zamieszczona [w:] tamże, s. 202.
} 
Dla pracowników dołowych alkohol odgrywał wielką rolę, jednak czy zdawali sobie sprawę, że stanowił on dla nich, a także dla ich rodzin, istotny problem? Chyba nie można udzielić jednoznacznej odpowiedzi na to pytanie. Jedni znali negatywne skutki swego nałogu, inni nie przejmowali się nimi. Jednak prawdą jest, że górnicy usprawiedliwiali swe zamiłowanie do wódki, jak już to zostało wyżej opisane. $Z$ całej zebranej literatury nie odnotowałam ani jednego przykładu, w którym górnicy przyznawaliby się, że piją z własnej winy. Wskazywali tylko na powody, które niejako „zmuszały" ich do sięgania po kieliszek. I tak na przykład pewien robotnik skarżył się na brak kąpieli w kopalni. Twierdził on, że gdy górnik jest cały brudny po pracy, to częstokroć nie jest w stanie pokonać długiej drogi do domu, dlatego musi odpoczaći i wstępuje często do karczmy, gdzie zostawia ciężko zarobione pieniądze. Gdyby zaś wziął kąpiel w kopalni, szedłby prosto do domu i nie wstępowałby do karczmy ${ }^{43}$. Czy naprawdę brak kąpieli w kopalni zmuszał robotników do wchodzenia do karczmy? Może rzeczywiście tak było ${ }^{4}$. Jednak z drugiej strony, powyższy przykład może oznaczać świadome zrzucenie odpowiedzialności za pijaństwo na kierowników kopalń i domaganie się tym samym zapewnienia kąpieli w miejscu pracy. Oczywiście każdy robotnik inaczej tłumaczył pociąg do wódki.

Zarówno Kościół jak i pracodawcy na łamach prasy poruszali omawiany w tej pracy problem. Wydawany wówczas w Bytomiu „Katolik” zajmował się między innymi kształtowaniem postaw obywatelskich, piętnując tym samym zgubne w skutkach zamiłowanie górników do alkoholu. Redaktorzy, czyli osoby spoza społeczności górniczej, z innej perspektywy patrzyli na nałogi pracowników dołowych. Przyczyn pijaństwa doszukiwali się zatem w zachowaniu górników, nie usprawiedliwiali ich tak, jak to czynili sami robotnicy. Niejednokrotnie potępiali ich zachowanie i wskazywali na negatywne skutki pijaństwa ${ }^{45}$.

Z Kolei czasopismo „Praca” nakreślało model idealnego robotnika na tle państwa, Kościoła, zakładu pracy i rodziny. Gazeta ta bardzo często wskazywała na idealne cechy śląskiego robotnika: nie powinien on chodzić do karczmy, nie może trzymać w domu wódki, nie powinien nosić ze sobą tzw. „piersiówki", świadomy jest nędzy pijaka umierającego w szpitalu i in. ${ }^{46}$. Jednak przyczyn pijaństwa „Praca” doszukiwała się głównie w otaczającym górnika świecie, nie zaś w jego zachowaniu. Tak na przykład winę za to, że mężczyzna chodzi do karczmy, gazeta zrzucała na jego żonę, która, nie radząc sobie z domowymi obowiązkami, niejako prowokuje męża do pijaństwa ${ }^{47}$. Odchodząc od przyczyn, należy jednak wskazać, że gazeta ta ostro krytykowała problem alkoholowy, ponieważ wielokrotnie wskazywała na jego negatywne skutki, które przyrównywała do tragedii rodzinnej. W nałogu alkoholowym „Praca” widziała szkodliwe następstwa, które godziły w dobro jednostki, w porządek społeczny, a także w moralne zasady życia rodzinnego. Mówiła nawet o psychodegradacji alkoholowej człowieka, u którego zanikają uczucia rodzinne, moralne i społeczne, poczucie obowiązku i godności osobistej, ambicja. Choroba ta prowadzi do degeneracji i degradacji społecznej, nieczystości i przestępczości ${ }^{48}$. Czasopismo to zatem bardzo poważnie traktowało problem alkoholowy i poprzez wskazywanie związanych z nim zagrożeń, podejmowało walkę z plagą pijaństwa.

Także Kościół zabiegał o trzeźwość górnośląskich robotników. Księża podkreślali, że pijaństwo niesie za sobą niereligijność i bezbożność. Kapłani obawiali się, że problem alkoholowy przyniesie

${ }^{43}$ Od Zabrza, „Katolik” 1889, nr 64. Cyt. za: W. Janota, Górny Ślask przed stu laty..., dz. cyt., s. 22-23.

44 Czasami górnicy potrzebowali nawet dwóch godzin, aby przybyć do kopalni.

45 Od Gliwic i Katowic pisza robotnicy tak, „,Katolik” 1884, nr 25. Cyt. za: W. Janota, Górny Ślask przed stu laty..., dz. cyt., s. $46-47$.

46 J. Wycisło, Model chrześcijańskiego robotnika górnoślaskiego w końcu XIX w., Katowice 1991, s. 67.

47 Tamże, s. 53-54.

48 Tamże s. 67 
zgubne następstwa dla moralności robotników. Powodów nałogu dopatrywali się w beznadziejnej sytuacji górników $w^{49}$. Kościół, opisywał złe położenie rodzin, w których występował ten problem. Podkreślał jednak zwłaszcza te negatywne następstwa, które godziły w ostoję religijności. Pijaństwo powodowało utratę wiernych. Zjawisko zmniejszenia ilości osób uczestniczących w niedzielnej mszy musiało być dość znaczne, skoro pisano o tym na łamach gazet. Kościół podejmował walkę z powszechnym zwyczajem chodzenia do karczmy w trosce o morale Ślązaków i dobro biednych rodzin ${ }^{50}$. Propagatorami akcji trzeźwościowych byli wtedy zwłaszcza księża ${ }^{51}$.

Jak podają sami górnicy, za pijaństwo często byli karani przez kierowników kopalń. Pewien robotnik skarżył się na przełożonego, który za przyczynę nędzy pracowników dołowych podawał pijaństwo ${ }^{52}$. Z kolei autor listu nadesłanego do „Katolika” skarży się na robotników, którzy chodzą do karczmy, aby pokazać, że stać ich na taki sam luksus jak urzędników. Ci ostatni z kolei, zapisują sobie robotników, którzy przeszkadzają im w bilardzie i przy wypłacie zmniejszają im zarobki ${ }^{53}$. Z listu tego wynika, że urzędnicy karali górników za pijaństwo, jednak poza terenem kopalni. Aby odpowiedzieć sobie na pytanie, czy stosowali jakiejś represje za pijaństwo na terenie kopalni, najpierw należy się zastanowić, czy taki problem w ogóle istniał. Z jednej strony, górnik wiedział, jakie niebezpieczeństwo kryje się pod ziemia, a także jakie kary grożą za przychodzenie do pracy w stanie nietrzeźwym. Jednak kilka czynników wskazuje na to, że problem ten występował także podczas pracy. W jednej z kopalni Hochbergó ${ }^{54}$ w Księstwie Pszczyńskim, zarzucano sztygarowi $^{55}$, o nazwisku Leonhartd, że handluje gorzałką i chlebem w kopalni ${ }^{56}$. Charakterystyczne także jest to, że za pijaństwo pod ziemią straszono górników Skarbnikiem ${ }^{57}$. Robotnicy wierzyli, że duch kopalni może ich ukarać między innymi za picie alkoholu w czasie pracy ${ }^{58}$. Nie ulega wątpliwości fikcyjność mitycznej postaci, jednak sama groźba kary wskazuje już na obecność problemu. Jednak najlepszym dowodem będzie relacja górnika, który przyznaje się do nietrzeźwości na kopalni. Opisuje pewną niedzielę, kiedy był na imieninach u kolegi. Miał iść na nocną zmianę, jednak się upił i poszedł na następna, poranną zmianę. Sztygar zauważył jednak w jakim jest stanie i chciał mu wypisać karę. Górnik jednak zwolnił się na własną odpowiedzialnośćs9. Robotnik wolał opuścić zakład pracy na własną rękę, niż podlegać karze wymierzonej mu przez przełożonego. Nie wiadomo, na jak dużą skalę występował problem pijaństwa w kopalni, ponieważ brak materiałów na ten temat. Niewiele jest relacji, $w$ których górnicy sami przyznawaliby się do picia w czasie pracy. Można jedynie przypuszczać, że skoro istniały zakazy i kary za spożywanie alkoholu na terenie kopalni, problem ten nie należał do rzadkości.

${ }^{49}$ Lipiny, „Katolik” 1879, nr 51. Cyt. za: W. Janota, Górny Śląsk przed stu laty..., dz. cyt., s. 43-44.

50 I. Bukowska-Floreńska, Rodzina..., dz. cyt., s. 103.

51 Wielkimi propagatorami akcji abstynencji byli na przykład ksiądz J. Ficek i ksiądz infułat J. Kapica.

52 Dab, „Katolik”1882, nr 4. Cyt. za: W. Janota, Górny Ślask przed stu laty..., dz. cyt., s. 21.

Lipiny , „Katolik"1882, nr 8. Cyt. za: W. Janota, Górny Ślask przed stu laty..., dz. cyt., s. 44-45.

54 Hochberg von Pless - książęta pszczyńscy. W pierwszej połowie XIX wieku i drugiej połowie wieku XX byli to: Jan Henryk X, Jan Henryk XI, Jan Henryk XV.

55 Nazwa stanowiska kierowniczego w kopalni, dozór techniczny.

56 S. Hosoda, Położenie socjalne robotników w górnictwie weglowym w dobrach ksiażąt pszczyńskich na Górnym Ślasku 1847-1870, Wroclaw 1997, s. 91.

57 Skarbnik to duch kopalni. Mógł być on dobry i zły, karać i nagradzać. Mógł przybierać różne kształty, jednak posiadał pewne przedmioty, dzięki którym można go było rozpoznać - lampa górnicza i kilof. Nie wiadomo kiedy ani dlaczego Skarbnik pojawił się w wierzeniach Górnoślązaków.

${ }_{58}$ M. G. Gerlich, Rytm..., dz. cyt., s. 61.

${ }^{59}$ M. Żywirska, Życiorysy..., dz. cyt., s. 83. Górnikiem, który opisuje te wydarzenia, był P. Gajowski. 


\section{ZAKońCZenIE}

Skutki pijaństwa były tragiczne. Górnicy zostawiali w karczmie część swojego, i tak już małego, zarobku. To z kolei wpływało na zubożenie rodzin, złe warunki bytowe. Niejednokrotnie pijany górnik wszczynał w domu awantury. Gdy nałóg dostrzegali urzędnicy, robotnik był karany, co także przynosiło szkodę jego rodzinie. To chyba najbardziej charakterystyczne, negatywne skutki, jakie niósł za sobą problem alkoholowy. Czy można jednak wymienić pozytywne następstwa opilstwa? Jeżeli takie występowały, to odczuwał je jedynie górnik, zaś z jego rodziną nie miały one nic wspólnego. Alkohol umożliwiał robotnikowi wkupienie się do górniczego kolektywu, zapewniał mu szacunek współpracowników, a także krótkotrwałe odprężenie w trudnych chwilach życia. Wynika z tego, że niejednokrotnie górnik bardziej cenił sobie własne korzyści, które wynosił z pijaństwa, niż negatywne konsekwencje, które dotykały jego rodzinę. Jednak stwierdzenie takie jest zbyt krzywdzące, ponieważ nie uwzględnia warunków, w jakich przyszło górnikom wtedy żyć. Jakakolwiek ocena ich postępowania, z naszej perspektywy czasu, będzie, moim zdaniem, błędna. Oceniać tę sytuację mogli jedynie ci, których problem ten bezpośrednio dotykał.

Na potrzeby pracy zastosowałam rozróżnienie między pijaństwem, a alkoholizmem, wykazując różnice miedzy tymi zjawiskami. W założeniach wstępnych stwierdziłam, że górników charakteryzowało pijaństwo. Byłoby jednak naiwnością twierdzić, że robotnicza społeczność górnośląska sięgała po alkohol jedynie ze względu na presję i obyczaje panujące $w$ danym regionie. Powodów do pijaństwa w życiu górnika było mnóstwo, a zwyczaje panujące w jego domu niejako nakazywały mu otaczać się trunkami. Często jednak pracownik dołowy sięgał po alkohol z własnej, nieprzymuszonej woli i takie zachowanie dalekie było od podtrzymywania tradycji. W ten sposób górnik bardzo często z pijaka zmieniał się w alkoholika. Zatem granica między tymi dwoma zjawiskami była bardzo cienka. Toteż niejednokrotnie nie wiadomo czy sprawa dotyczyła pijaka, czy już alkoholika, ponieważ ilość różnych powodów do świętowania była tak duża, że często nie można było odróżnić tych dwóch stanów. Pijaństwo i alkoholizm przenikały się tak dalece, że nieraz trudno je było rozgraniczyć. Mimo iż rozróżnienie to może wydawać się sztuczne, uważam, że było konieczne ze względu na rolę, jaką pełnił alkohol wśród górnośląskich górników.

Czy w pijaństwie można widzieć rodzaj obyczaju charakterystycznego dla omawianej grupy zawodowej? Jestem skłonna odpowiedzieć na to pytanie twierdząco. Traktując obyczaj jako ustalony sposób postępowania w danych okolicznościach, który charakteryzuje określoną grupę społeczną ${ }^{60}$, można stwierdzić, że pijaństwo wpisuje się w te sztywne normy. Za zaliczeniem omawianego zagadnienia do grona obyczajów dawnych górników przemawia fakt, że był on przekazywany z pokolenia na pokolenie i zanikowi ulegał bardzo powoli, zaś jego naruszenie powodowało negatywną reakcję ze strony grupy. To tradycja nakazywała zarówno spożywanie alkoholu, jak i częstowanie nim innych. Górnośląskich robotników charakteryzowała rodzinna tradycja zawodowa, która polegała na „dziedziczeniu” określonego zawodu przez kolejne pokolenie w tych samych rodzinach ${ }^{61}$. Uważam, że wraz z „,dziedziczeniem” zawodu, górnicy przejmowali pewne zachowania i zwyczaje związane z pracą pod ziemia, w tym pijaństwo. Młodzi chłopcy, obserwując swych ojców, wynosili niejednokrotnie z domu "zamiłowanie" do wódki. Nazywając pijaństwo obyczajem, nie można tego samego powiedzieć o alkoholizmie, gdyż był to niezamierzony skutek, który bardzo często wynikał z tego pierwszego zjawiska.

Warto także zaznaczyć, że przedstawiony problem nie był jednoznaczny, chociaż czytelnik może odnieść takie wrażenie. Pijaństwo wśród górników było bardzo częstym zjawiskiem, jed-

60 M. Szymczak (red.), Stownik języka polskiego, Warszawa 1979, s. 434.

61 W. Mrozek, Górnoślaska rodzina..., dz. cyt., s. 120-121. 
nak nie można utożsamiać każdego dawnego górnika z pijakiem czy alkoholikiem, ponieważ takie postrzeganie prowadziłoby do stereotypu i byłoby krzywdzace dla tej grupy zawodowej. Należy mieć świadomość, że praca ta stanowi tylko ogólna, przybliżoną charakterystykę stanu górniczego. Z całą pewnością pijaństwo nieco inaczej przedstawiało się w poszczególnych okręgach Górnego Śląska. Raz mogło być bardziej widoczne w Raciborskim, a raz w Rybnickim. Regiony, a w ich obrębie wioski, różniły się między sobą nie tylko różnorodnością obrzędów, ale także pod względem intensywności problemu alkoholowego. Przeważnie była to sprawa ogólnospołeczna, ale jej przebieg, przyczyny i skutki były sprawą indywidualną każdej jednostki. Nie ma jednak wațpliwości, że istniało ogólne przyzwolenie na pijaństwo, gdyż bez niego, zjawisko to nie byłoby w stanie rozprzestrzenić się na tak wielką skalę.

\section{Bibliografia}

Bonczyk N., Stary Kościót Miechowski, t. 1, Katowice 1936.

Bukowska-Floreńska I., Rodzina na Górnym Ślasku, Katowice 2007.

Bukowska-Floreńska I., Społeczno-kulturowe funkcje tradycji w społecznościach industrialnych Górnego Ślaska, Katowice 1987.

Gerlich H., Gerlich M. G., Zwyczaje, obyczaje i obrzędy rodzinne w miastach Górnego Śląska (od schyłku XIX w. do połowy XX w.), "Zaranie Śląskie” 1989, R. LII, nr 3/4.

Gerlich H., Gerlich M., Sacrum. Rodzina. Tradycje, Katowice 1995.

Gerlich H., Narodziny, zaślubiny, śmierć, Katowice 1984.

Gerlich M., Rytm i obyczaj. Cztery szkice o tradycyjnej kulturze górniczej, Zabrze 2003.

Górnikowska-Zwolak E., Szkic do portretu Ślazaczki. Refleksja feministyczna, Katowice 2004.

Hosoda S., Położenie socjalne robotników w górnictwie węglowym w dobrach książą pszczyńskich na Górnym Ślasku. 1847-1870, Wrocław 1997.

Janota W., Górny Śląsk przed stu laty. Jak o nim gazety owoczesne pisały, Katowice 1984.

Jaros J., Historia górnictwa węglowego w Zagłęiu Górnośląsim do 1914 roku, Wrocław-Warszawa-Kraków 1965.

Kurek J. (red.), Kultura i obyczajowość mieszkańców Chorzowa w XIX i XX wieku, Chorzów Batory 2001.

Michalkiewicz S., Przemyst i robotnicy na Slasku, Katowice 1984.

Mrozek W., Górnośląka rodzina robotnicza w procesie przeobrażeń, Katowice 1987.

Piecha B., Barbara. Barbórka. Święta. Kult Świętej Barbary na Górnym Śląsku. Literatura i sztuki piękne, Katowice 2002.

Simonides D. (red.), Górniczy stan w wierzeniach, obrzędach, humorze i pieśniach, Katowice 1988.

Simonides D., Najpiękniejsze zwyczaje i obrzędy górnośląskie, Katowice 1995.

Simonides D., Od kolebki do grobu, Opole 1988.

Szymczak M. (red.), Stownik języka polskiego, t. 2, 3, Warszawa 1979.

Wycisło J., Model robotnika chrześcijańskiego w ujęciu górnoślaskiego czasopisma „Praca” (1890 - 1891), „Śląskie Studia Historyczno-Teologiczne", 1982, R. XV.

Wycisło J., Model chrześcijańskiego robotnika górnoślaskiego w końcu XIX w., Katowice 1991.

Ziemba J., Stromą na dót drabiną. Z tradycji polskiego górnictwa, Katowice 1983.

Żywirska M., Gawędy górnicze, Warszawa 1968.

Żywirska M., Życiorysy górników, Katowice 1949.

\section{Netografia}

Olejnik A., Pijaństwo a alkoholizm, http://www.adamolejnik.com/blog/2008/02/13/pijanstwo-a-alkoholizm/, 30.05.2010.

\section{Relacje USTNe}

Ciuberek Aniela, 10.04.2010, Rogów.

Lorenc Violetta, 16.04.2010, Wodzisław Śląski.

Sosna Gertruda, 09.04.2010, Łaziska Rybnickie.

Surma Henryk, 02.04.2010, Godów.

Surma Krystyna, 03.04.2010, Godów.

Wodecka Gertruda, 09.04.2010, Łaziska Rybnickie. 


\section{Słowa kluczowe}

Pijaństwo na Górnym Śląsku, pijaństwo, Górny Śląsk, górnicy

\section{STRESZCZENiE}

Przedmiotem pracy jest problem alkoholowy, który występował wśród górników górnośląskich na przełomie XIX i XX wieku. Opisałam najbardziej charakterystyczne momenty w życiu pracowników górnośląskich, którym towarzyszył alkohol, czyli różnego rodzaju święta, biesiady i spotkania. Pijaństwo tego okresu było związane z mentalnością środowisk górniczych, a także z ich życiem codziennym i religijnym, dlatego odwołałam się do poszczególnych etapów życia tej grupy zawodowej.

Praca ta, chociaż dotyczy wydarzeń mających miejsce w XIX i XX wieku, swym zasięgiem obejmuje granice dzisiejzzego Górnego Śląska, jednak bez Zagłębia Dąbrowskiego.

Na potrzeby pracy zastosowałam rozróżnienie między pijaństwem, a alkoholizmem, wykazując różnice między tymi zjawiskami. Starałam się także wyjaśnić przyczyny sięgania po alkohol.

\section{DRUNKENNESS OF MINERS IN UPPER Silesia IN THE SECOND HALF OF $19^{\mathrm{TH}}$ CENTURY AND THE FIRST HALF OF $20^{\text {TH }}$ CENTURY. Collective PORTRAit}

\section{Keywords}

Drunkenness in Upper Silesia, drunkenness, Upper Silesia, miners

\section{Summary}

The subject of this article is alcohol-related problem among Upper Silesia miners at the turn of $19^{\text {th }}$ century. I described the most characteristic moments of Upper Silesia employees' lives in which alcohol was present, such as different kinds of holidays, feasts and gatherings. Drunkenness in this period of time was connected to miners' social environment's mentality and to their everyday and religious life. That is why I referred to various stages of this professional group's lives.

The range of this article, although it concerns events from $19^{\text {th }}$ and $20^{\text {th }}$ century, includes the territory of today's Upper Silesia, but without Zagłębie Dąbrowskie (Coal Fields of Dąbrowa). For the needs of the article I made a division between alcoholism and drunkenness, explaining the differences between these phenomena. I tried to explicate the reasons of drinking as well. 